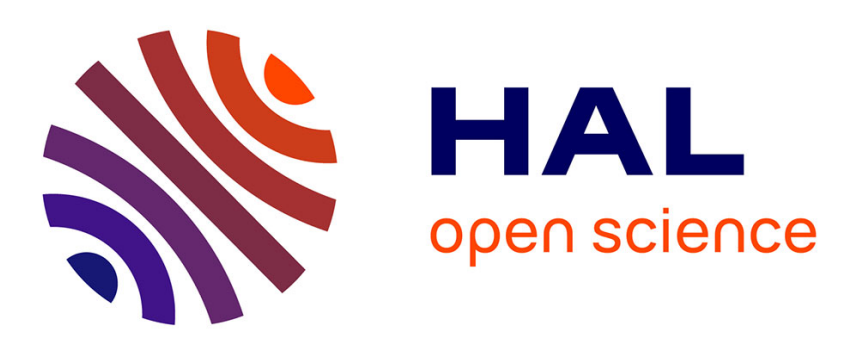

\title{
Vasculoprotective Effects of Somatostatin Receptor Subtypes
}

Nina-Maria Tigerstedt, Einari Aavik, Silja Aavik, Hanna Savolainen-Peltonen, Pekka Hayry

\section{- To cite this version:}

Nina-Maria Tigerstedt, Einari Aavik, Silja Aavik, Hanna Savolainen-Peltonen, Pekka Hayry. Vasculoprotective Effects of Somatostatin Receptor Subtypes. Molecular and Cellular Endocrinology, 2007, 279 (1-2), pp.34. 10.1016/j.mce.2007.08.018 . hal-00531950

\section{HAL Id: hal-00531950 \\ https://hal.science/hal-00531950}

Submitted on 4 Nov 2010

HAL is a multi-disciplinary open access archive for the deposit and dissemination of scientific research documents, whether they are published or not. The documents may come from teaching and research institutions in France or abroad, or from public or private research centers.
L'archive ouverte pluridisciplinaire HAL, est destinée au dépôt et à la diffusion de documents scientifiques de niveau recherche, publiés ou non, émanant des établissements d'enseignement et de recherche français ou étrangers, des laboratoires publics ou privés. 


\section{Accepted Manuscript}

Title: Vasculoprotective Effects of Somatostatin Receptor Subtypes

Authors: Nina-Maria Tigerstedt, Einari Aavik, Silja Aavik, Hanna Savolainen-Peltonen, Pekka Hayry

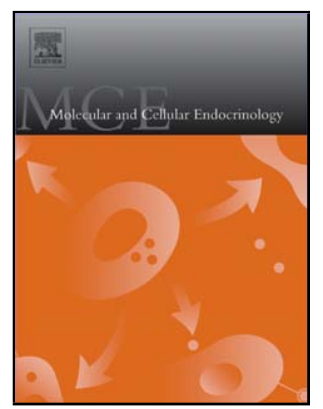

PII:

S0303-7207(07)00339-5

DOI: doi:10.1016/j.mce.2007.08.018

Reference: MCE 6707

To appear in: $\quad$ Molecular and Cellular Endocrinology

Received date: $\quad 29-4-2007$

Revised date: $\quad$ 8-7-2007

Accepted date: $\quad 31-8-2007$

Please cite this article as: Tigerstedt, N.-M., Aavik, E., Aavik, S., Savolainen-Peltonen, H., Hayry, P., Vasculoprotective Effects of Somatostatin Receptor Subtypes, Molecular and Cellular Endocrinology (2007), doi:10.1016/j.mce.2007.08.018

This is a PDF file of an unedited manuscript that has been accepted for publication. As a service to our customers we are providing this early version of the manuscript. The manuscript will undergo copyediting, typesetting, and review of the resulting proof before it is published in its final form. Please note that during the production process errors may be discovered which could affect the content, and all legal disclaimers that apply to the journal pertain. 


\section{Vasculoprotective Effects of Somatostatin Receptor Subtypes}

Nina-Maria Tigerstedt, Einari Aavik, Silja Aavik, Hanna Savolainen-Peltonen, and Pekka Hayry

Rational Drug Design Programme, Biomedicum Helsinki and Transplantation Laboratory, University of Helsinki and Helsinki University Central Hospital, Helsinki, Finland.

\section{Correspondence}

Nina-Maria Tigerstedt, MD, Transplantation Laboratory, PO Box 21 (Haartmaninkatu 3), FIN

00014 University of Helsinki, Finland, tel: +358-9-1911, fax: +358-9-2272411, e-mail: ninamaria.tigerstedt@helsinki.fi

\section{Sources of support}

Supported by grants from the Academy of Finland, the Sigrid Juselius Foundation, Finska Läkaresällskapet, Nylands Nation and Helsinki University Central Hospital Research Funds, Helsinki, Finland

\section{Word count}

Summary 153

Total text 2700

Figures 2, Tables 1 
Keywords: (rat carotid) arterial injury; somatostatin analogs; somatostatin receptor; smooth muscle cell; (rat aortic) tissue explant

\section{Summary}

We have shown that somatostatin agonist peptide $\mathrm{CH} 275$, selective to somatostatin receptor (sst) subtypes 1,4 , was more effective in preventing intimal hyperplasia than the sst2,3,5-selective octreotide, raising the question what are the separate roles of the sst1- and 4-subtypes. Here we dissect this observation further with highly subtype-selective peptidomimetics and demonstrate that, after rat carotid denudation, both the sst1- and 4-selective analogs (300 $\mu \mathrm{g} / \mathrm{kg} / \mathrm{d}$, s.c.) increased lumen size, while only the sst4-selective analog significantly reduced intimal nuclei number, intimal area, and intima/media ratio. The 2,3,5-selective compounds had no effect on these parameters. The observed in vivo effects were further investigated ex vivo with explant outgrowth from pieces of vascular wall. The sst4-selective analog was more effective than the sst1-selective one in inhibiting the percent of outgrowth and the migration of cells from the explants while neither compound affected proliferation. Thus, selective targeting to sst 4 should be considered when developing orally active vasculoprotective therapies. 


\section{Introduction}

Five distinct somatostatin receptor (sst) genes encode five 7-transmembrane proteins within the superfamily of G-protein-coupled receptors. Somatostatin receptors can be divided into two subsets, the sst2,3,5 and sst1,4 (Moller et al., 2003; Olias et al., 2004). Agonists selective to sst2,3, and 5 (octreotide and lanreotide) have been studied in rodents, rabbits, and pigs (referred to in Aavik et al., 2002) yielding promising results in preventing intimal hyperplasia after denudation injury. However, three multicenter clinical trials for the prevention of reocclusion or clinical events after percutaneous transluminal angioplasty, failed to show more than a marginal effect with lanreotide (Emanuelsson et al., 1995; Eriksen et al., 1995) and no effect with octreotide (von Essen et al., 1997).

In rat aorta the predominant receptor subtypes are sst1 and 4 (Khare et al., 1999). After denudation injury their expression increases acutely, whereas the expression of sst2 remains low and that of sst5 is nearly non-existent. More importantly, the predominant subtypes in atherosclerotic human vessels are also sst1 and 4 (Curtis et al., 2000).

We have previously shown superior vasculoprotective effects with the somatostatin peptide analog CH275 (Aavik et al., 2002), selective to sst1 and 4 (Patel, 1999), compared to only marginal effect with sst2,3- and 5-selective octreotide, or nonselective somatostatin-14 (Patel, 1999; Reisine and Bell, 1995). The question remains, which of the two candidate receptors, sst1 or 4, should preferentially be targeted in drug design.

In this communication, we have dissected the mechanism of the vasculoprotective effect further, using five sst subset-selective agonist peptidomimetics in an in vivo plus ex vivo experimental setup. 


\section{Methods}

\subsection{Denudation Injury}

Male Wistar rats (250-300 g, Harlan, Horst, The Netherlands) underwent carotid denudation ( $\mathrm{n}=5$ per group) (Clowes et al. 1983) to quantitate drug effects in vivo. As carotid artery did not yield sufficient tissue material, aortic denudation ( $\mathrm{n}=3$ per group) (Myllarniemi et al., 1997) was used instead to evaluate ex vivo explant outgrowth. The rats were anesthetized with chloral hydrate (240 $\mathrm{mg} / \mathrm{kg}$ ip.), and buprenorphine (0.25 mg/kg sc., Reckitt \& Coleman, Hull, England) was given for peri- and postoperative pain relief. The investigation conforms to the Guide for the Care and Use of Laboratory Animals published by the US National Institutes of Health (NIH Publication no. 8523, revised 1996).

\subsection{Peptidomimetics and Drug Administration}

Non-peptide agonists for each of the five somatostatin receptors, L-797,591 (sst1), L-779,976 (sst2), L-796,778 (sst3), L-803,087 (sst4), and L-817,818 (sst5) (Rohrer et al., 1998) were a gift from Dr Susan P. Rohrer, Merck \& Co., Inc., Rahway, NJ. For their design and affinities, see Rohrer et al. 1998. The agonists were dissolved in DMSO and diluted in PBS, and were given as a single s.c. injection per day, beginning at operation. The animals received vehicle or the peptidomimetics at a dose of $300 \mu \mathrm{g} / \mathrm{kg}$, an optimal effective dose recommended by the manufacturer, and they were weighed daily.

\subsection{Histological Evaluation of In Vivo Specimens}


Carotid mid-section specimens were obtained upon sacrifice on day 14, fixed in paraformaldehyde, and stained with Mayer's hematoxylin-eosin, Masson's connective tissue, and silver elastic stainings, as described (Aavik et al., 2002). Intima and media cell numbers were counted and the histological picture was digitalized with an Olympus video microscope and quantitated using Macintosh NIH-Image Ver.1.62 software to derive the following parameters: intima area, media area, intima/media area ratio, and perimeter length (Aavik et al., 2002).

\subsection{Ex vivo Aortic Explants}

Explants measuring $1 \times 1 \mathrm{~mm}$ were prepared from the rat aorta with a McIlwain tissue chopper (Mickle Laboratory Engineering, Surrey, England) (Aavik et al., 2002) and cultured individually in wells of flat-bottomed 96-well plates (Nunc, Roskilde, Denmark). Ligands were administered at the dose of $300 \mu \mathrm{g} / \mathrm{kg} / \mathrm{d}$ in vivo, as described earlier.

Each well was observed at $48 \mathrm{~h}$ and considered positive for outgrowth if any number of cells had grown out of the explant. The distance of the leading edge from the explant (migration) was measured using a calibrated graticule (Olympus, Tokyo, Japan). Proliferation was measured by ${ }^{3} \mathrm{H}-$ TdR incorporation.

\subsection{Statistical Analysis}

Data are presented as mean \pm SEM. The data were evaluated with one-way ANOVA with Dunnett's correction to compare the treatment groups to the control group, or in the case of non-parametric comparisons with the Kruskal-Wallis test with Dunn correction. $\mathrm{P}<0.05$ was considered statistically significant. 


\section{Results}

\subsection{Effect of Peptidomimetics on Vascular Injury Response In Vivo}

Drug treatment (300 $\mu \mathrm{g} / \mathrm{kg} / \mathrm{d}$ s.c., an optimal dose recommended by the manufacturer) was welltolerated and there was no weight difference between vehicle and drug-treated rats (not shown).

The results of quantitative histology on carotid mid-section samples obtained 14 days after denudation injury are shown in Figures 1 and 2. Intima cells of non-denuded rats, $58 \pm 1$ (SEM) per vessel circumference, consisted of the endothelial lining only. After denudation this increased to $505 \pm 46$ cells per circumference. Treatment with the sst1-selective agonist reduced the intima cell number to $305 \pm 80(\mathrm{p}=\mathrm{NS})$ and with the sst4-selective agonist to $299 \pm 53(\mathrm{p}<0.05)$. No effect was observed with the other compounds.

The intima area in nondenuded rats was barely measurable, $<0.26 \times 10^{-8} \mathrm{~m}^{2}$. After denudation, the intima area increased to $5.9 \pm 0.5 \times 10^{-8} \mathrm{~m}^{2}$. Treatment with the sst4-selective agonist reduced the intima area to $2.5 \pm 0.5 \times 10^{-8} \mathrm{~m}^{2}(\mathrm{p}<0.05)$. No significant effect was observed with the other compounds.

The media cell number of non-denuded rats, $168 \pm 17$ cells per vessel circumference, and media area, $9.2 \pm 0.6 \times 10^{-8} \mathrm{~m}^{2}$, increased in non-treated controls to $237 \pm 27$ cells, and $11.0 \pm 0.5 \times 10^{-8}$ $\underline{\mathrm{m}^{2}}$, respectively. Compared to non-treated controls, none of the drugs had any significant effect either on the media cell number or area. 
The intima/media area ratio reflects the changes in the media and intima areas. In denuded nontreated rats carotids it was $0.5 . \pm 0.1$. Treatment with the sst1-selective agonist reduced the ratio to $0.35 \pm 0.1(\mathrm{p}=\mathrm{NS})$ and with the sst4-selective agonist to $0.2 \pm 0.04(\mathrm{p}<0.05)$. No effect was observed with the other compounds.

The lumen perimeter length in non-denuded rats was $21.7 \pm 0.6 \times 10^{-4} \mathrm{~m}$ and it decreased to $20.6 \pm$ $\underline{0.6 \times 10^{-4} \mathrm{~m} \text { post-injury. Treatment with the sst1- and the sst4-selective agonist increased the }}$ perimeter length to $22.6 \pm 0.6 \times 10^{-4} \mathrm{~m}(\mathrm{p}<0.05)$ and $23.9 \pm 0.4 \times 10^{-4} \mathrm{~m}(\mathrm{p}<0.01)$, respectively. No significant effect was observed with the other compounds.

\subsection{Effects of Peptidomimetics on Vascular Explants Ex Vivo}

Recent evidence indicates that the paradigm of neointima cells deriving from the media (Thyberg, 1996) is not correct. Instead, the cells seem to derive from circulating precursors and are possibly recent immigrants from the bone marrow (Sata et al., 2002). To evaluate the effect of the sstagonists on cell proliferation and migration, an ex vivo setting was used. In this model, the denudation injury is initiated in vivo and explants from the injured vessels are cultured ex vivo for evaluation of cell outgrowth ("sprouting"), migration, and proliferation (Aavik et al., 2002).

In control rats, the frequency of sprouting explants increased from the $32.2 \pm 7.4 \%$ pre-denudation level to $85.7 \pm 4.1 \%(\mathrm{p}<0.0001)$ at $48 \mathrm{~h}$ of culture. The distance migrated increased from $116 \pm 31$

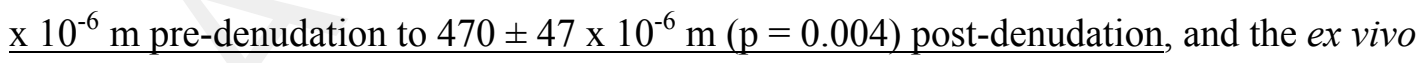
replication from $603 \pm 340 \mathrm{cpm}$ pre-denudation to $3885 \pm 495 \mathrm{cpm}$ post-denudation $(\mathrm{p}=0.040)$ (Table 1). 
The sst4-selective ligand inhibited explant outgrowth $(p<0.01)$ and migration $(p<0.05)$, but had no effect on cell replication in aortic explants. No significant effect on any one of the three parameters was observed with the other ligands, with the exception of a minor effect of the sst5-selective ligand on explant outgrowth $(\mathrm{p}<0.05)$ (Table 1). 


\section{Discussion}

Our earlier studies with agonist peptides show the significance of sst1 and 4 as targets for vasculoprotective therapy (Aavik et al., 2002). Furthermore, as ligands selective to sst1,3, and 4 do not display any "classical" somatostatin effects (Rohrer et al., 1998), we may hypothesize that by targeting exclusively to these receptors, but bypassing sst2 and 5, vasculoprotective compounds with no side-effects related to "classical" somatostatin functions could be generated. Our results with highly selective peptidomimetics show the superior vasculoprotective effect of the sst 4 analog. The sst1 analog reduced lumen size in vivo, but statistical significance was not reached with the other parameters measured. Interestingly, none of the other sst subtype-selective ligands had any effect on neointimal thickening in vivo.

Our results are not necessarily contradictory to earlier peptide studies, where vasculoprotective effects were demonstrated with sst2,3, and 5-selective agonists (Lundegan et al., 1989), as peptides previously used were not selective and might have cross-reacted with a wide range of receptors. Hence, the vasculoprotective effects of these peptide analogs could be due to cross-reactivity to sst1,4, or alternatively, due to a summation effect. Nevertheless, when targeted separately with highly selective peptidomimetics, the ligands selective to sst2, 3, and 5 failed to prevent vascular events after denudation injury.

As recent evidence indicates that neointimal cells derive at least partly from circulating precursors (Sata et al., 2002), in vitro cell line assays do not give a comprehensive picture of the effects of the compounds on the real neointimal cell population. To investigate the effects of the sst agonist peptidomimetics on the migratory and proliferative capacity of neointimal cells, without excluding 
the participation of precursor cells, we performed punch explants of denuded aorta and examined the outgrowth and replication of the explants ex vivo (Aavik et al., 2002).

In the ex vivo assay, only the sst4-selective ligand, when administered in vivo, significantly inhibited explant outgrowth and migration. No other compound affected any of the parameters measured, with the exception of the marginal effect of the sst5-selective analog on explant outgrowth, which may be due to cross-reactivity with sst1 or a summation effect (Rohrer et al., 1998). Furthermore, as our previous studies show that the precursor cell influx occurs within day 2 to 4 post-injury (Aavik et al., 2002), the same time frame that the explants were obtained for culture, the results suggest that sst 4 may particularly modulate precursor cell influx into the vascular wall.

In conclusion, of all five sst subtypes, only sst 4 has distinct roles in the inhibition of rat neointimal hyperplasia: sst4 modulates vascular precursor cell influx into the vessel and thus prevents the migration of these cells within the vessel wall. As the effect of the sst4 analog was superior in vivo, selectivity to sst4 should be considered in the development of optimal somatostatin agonist compounds for the prevention of vascular occlusion and restenosis. Further studies are needed to assess if these results will be also applicable in man. 


\section{Acknowledgements}

The study was supported by grants from the Academy of Finland, the Sigrid Juselius Foundation,

Finska Läkaresällskapet, Nylands Nation and Helsinki University Central Hospital Research Funds,

Helsinki. The somatostatin analogs were a gift from Dr Susan P. Rohrer, Merck \& Co., Inc. 


\section{References}

Aavik, E., Luoto, N.M., Petrov, L., Aavik, S., Patel, Y.C., Hayry, P., 2002. Elimination of vascular fibrointimal hyperplasia by somatostatin receptor 1.4 selective agonist. FASEB J. 16, 724-726.

Clowes, A.W., Reidy, M.A., Clowes, M.M., 1983. Mechanisms of stenosis after arterial injury. Lab. Invest. 49, 208-15.

Curtis, S.B., Hewitt, J., Yakubovitz, S., Anzarut, A., Hsiang, Y.N., Buchan, A.M., 2000.

Somatostatin receptor subtype expression and function in human vascular tissue. Am. J. Physiol. Heart Circ. Physiol. 278, H1815-22.

Emanuelsson, H., Beatt, K.J., Bagger, J.P., Balcon, R., Heikkila, J., Piessens, J., Schaeffer, M., Suryapranta, H., Foegh, M., 1995. Long-term effects of angiopeptin treatment in coronary angioplasty. Reduction of clinical events but not angiographic restenosis. European Angiopeptin Study Group. Circulation 91, 1689-96.

Eriksen, U.H., Amtorp, O., Bagger, J.P., Emanuelsson, H., Foegh, M., Henningsen, P., Saunamaki, K., Schaeffer, M., Thayssen, P., Orskov, H., 1995. Randomized double-blind Scandinavian trial of angiopeptin versus placebo for the prevention of clinical events and restenosis after coronary balloon angioplasty. Am. Heart J. 30, 1-8.

Khare, S., Kumar, U., Sasi, R., Puebla, L., Calderon, L., Lemstrom, K., Hayry, P., Patel, Y.C., 1999. Differential regulation of somatostatin receptor types 1-5 in rat aorta after angioplasty. FASEB J. 13, 387-94. 
Lundegan, C., Foegh, M.L., Vargas, R., Eufemio, M., Bormes, G.W., Kot, P.A., 1989.

Inhibition of myointimal proliferation of the rat carotid artery by the peptides, angiopeptin and BIM 23034. Atherosclerosis 80, 49-55.

Moller, L.N., Stidsen, C.E., Hartmann, B., Holst, J.J., 2003. Somatostatin receptors. Biochim Biophys Acta. 1616, 1-84.

Myllarniemi, M., Calderon, L., Lemstrom, K., Buchdunger, E., Hayry, P., 1997. Inhibition of platelet-derived growth factor receptor tyrosine kinase inhibits vascular smooth muscle cell migration and proliferation. FASEB J. 11, 1119-26.

Olias, G., Viollet, C., Kusserow, H., Epelbaum, J., Meyerhof, W., 2004. Regulation and function of somatostatin receptors. J Neurochem. 89, 1057-1091.

Patel, Y.C., Greenwood, M.T., Panetta, R., Demchyshyn, L., Niznik, H., Srikant, C.B., 1995. The somatostatin receptor family. Life Sci. 57, 1249-1265.

Patel, Y.C., 1999. Somatostatin and its receptor family. Front. Neuroendocrinol. 20, 157-98.

Reisine, T., Bell, G.I., 1995. Molecular biology of somatostatin receptors. Endocr. Rev. 16, 427-42.

Rohrer, S.P., Birzin, E.T., Mosley, R.T., Berk, S.C., Hutchins, S.M., Shen, D.M., Xiong, Y., Hayes, E.C., Parmar, R.M., Foor, F., Mitra, S.W., Degrado, S.J., Shu, M., Klopp, J.M., Cai, S.J., Blake, A., Chan, W.W., Pasternak, A., Yang, L., Patchett, A.A., Smith, R.G., Chapman, K.T., 
Schaeffer, J.M., 1998. Rapid identification of subtype-selective agonists of the somatostatin receptor through combinatorial chemistry. Science 282, 737-40.

Sata, M., Saiura, A., Kunisato, A., Tojo, A., Okada, A., Tokuhisa, T., Hirai, H., Makuuchi, M., Hirata, Y., Nagai, R., 2002. Hematopoietic stem cells differentiate into vascular cells that participate in the pathogenesis of atherosclerosis. Nat. Med. 8, 403-9.

Thyberg, J., 1996. Differentiated properties and proliferation of arterial smooth muscle cells in culture. Int. Rev. Cytol.169, 183-265.

von Essen, R., Ostermaier, R., Grube, E., Maurer, W., Tebbe, U., Erbel, R., Roth, M., Oel, W., Brom, J., Weidinger, G., 1997. Effects of octreotide treatment on restenosis after coronary angioplasty: results of the VERAS study. VErringerung der Restenoserate nach Angioplastie durch ein Somatostatin-analogon. Circulation 96, 1482-7. 


\section{Legends to the Figures}

Figure 1. The effect of sst1...5-selective agonist peptidomimetics on denudation injury response in male rat carotid artery. The data are expressed as mean $\pm \mathrm{SEM}, \mathrm{n}=5$. Circles represent controls, open boxes the sst2,3,5, and black boxes the sst 1 and 4 treatment groups. Normal vessel parameters are highlighted with a dark shadow and post-injury parameters for untreated rats with a light shadow.

Figure 2. Representative photomicrographs from paraffin cross sections of injured rat carotid arteries after 14 days of treatment with sst1, sst2, sst3, sst4, or sst5-selective analog. Controls include a normal and an injured, vehicle-treated carotid artery. Hematoxylin-eosin staining, x400. The arrows indicate the internal elastic laminae. 

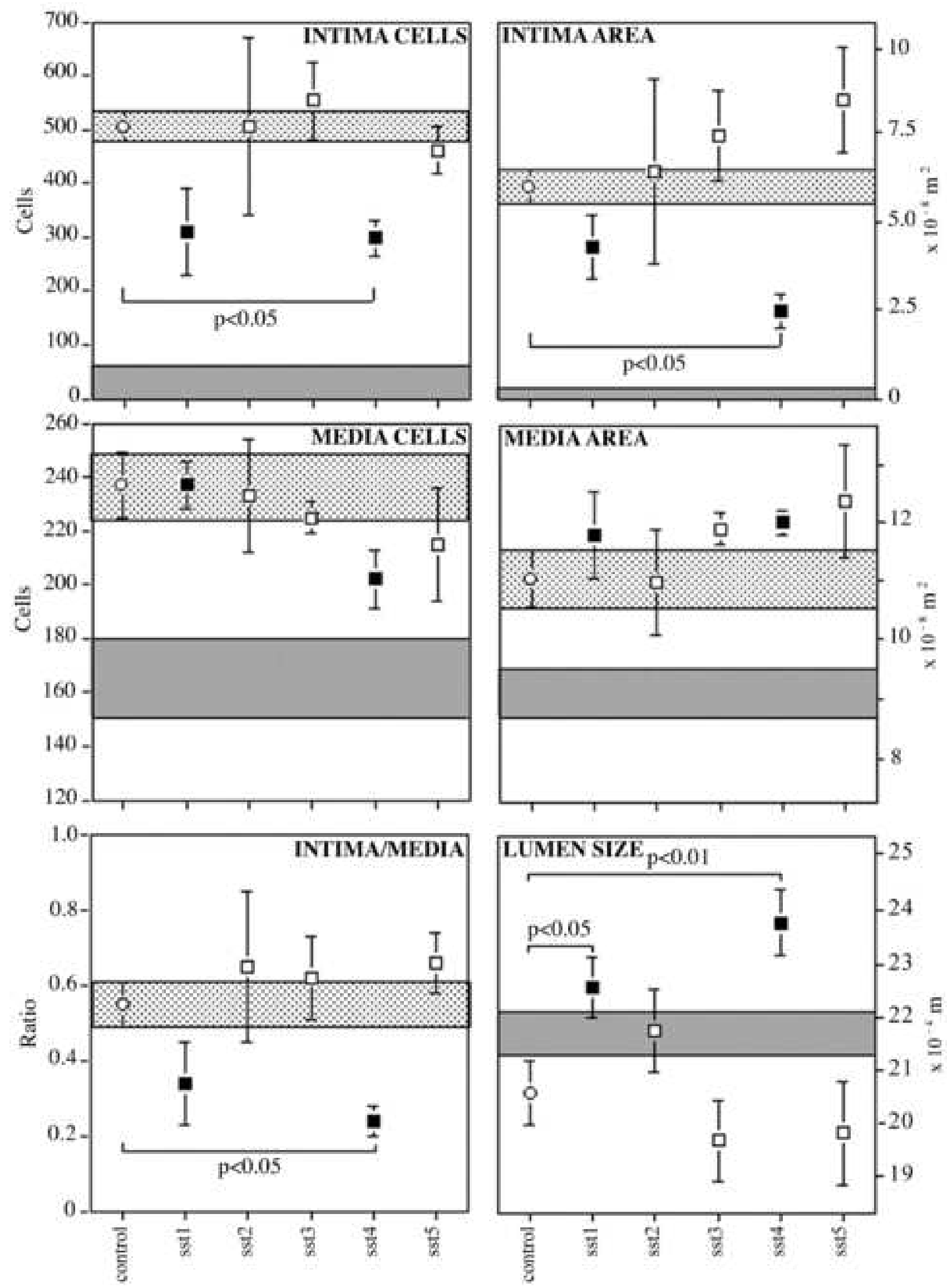


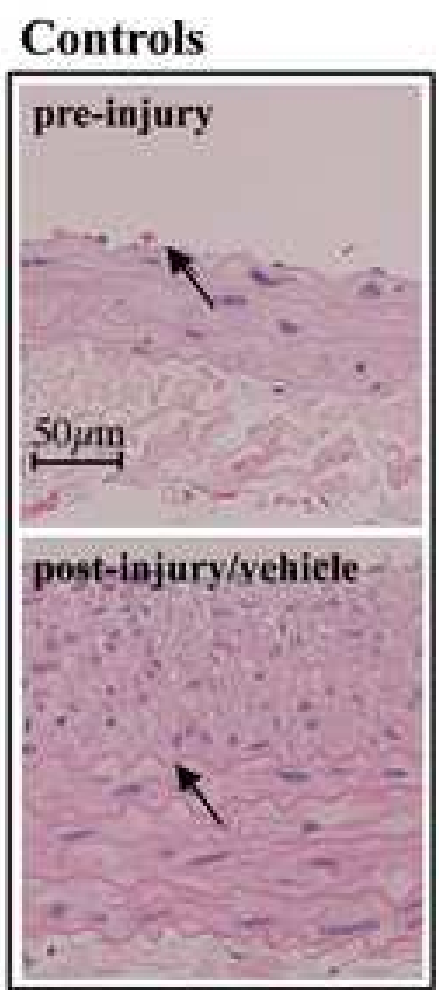

Drug treatment

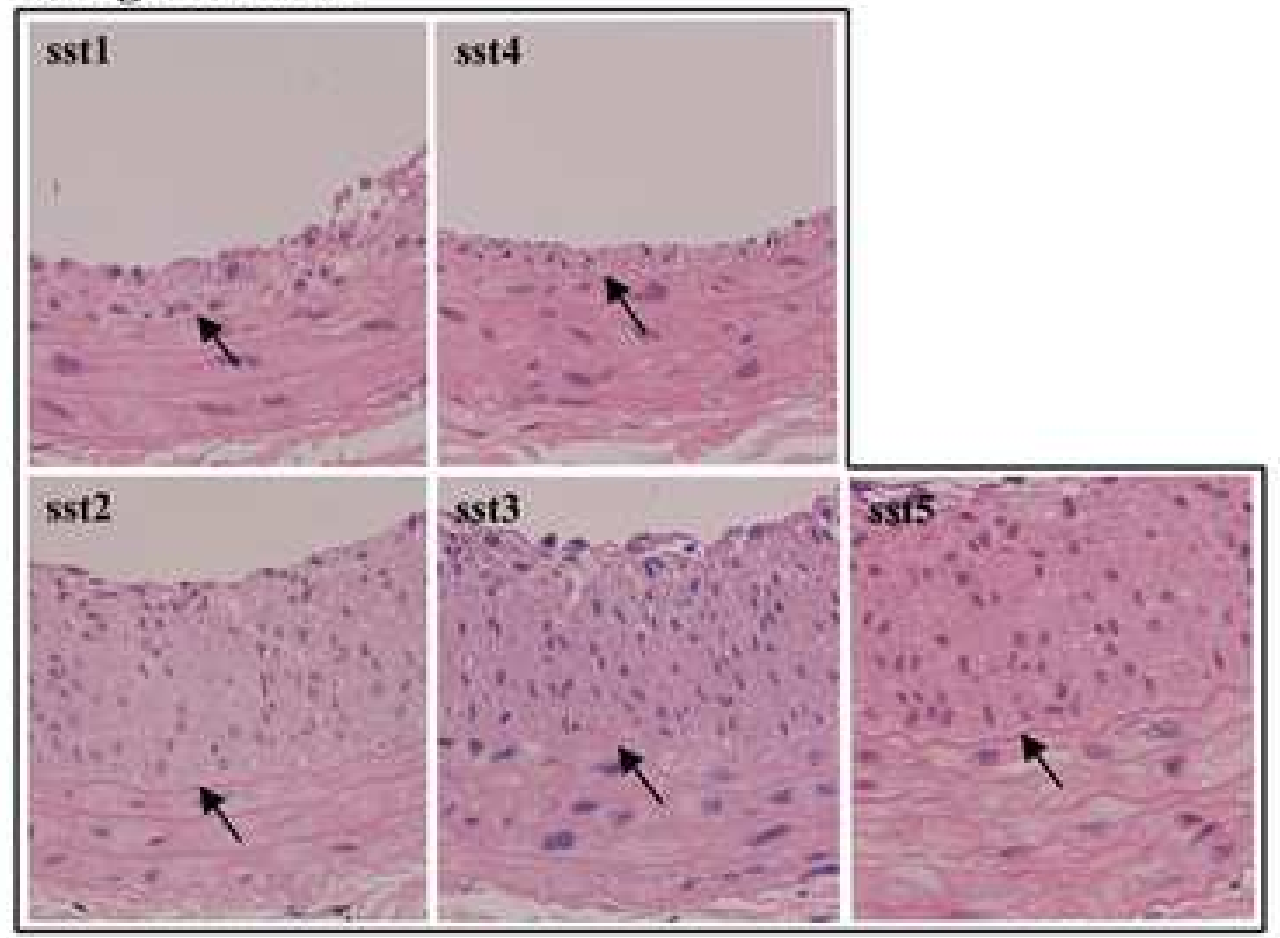


Table 1. Effects of Ligands on Explant Outgrowth

\begin{tabular}{llll}
\hline Ligand & Explant outgrowth $(\%)$ & Distance migrated $\left(\mathrm{x} 10^{-6} \mathrm{~m}\right)$ & Proliferation (cpm) \\
& & & \\
\hline Control & $85.7 \pm 4.1$ & $470 \pm 47$ & $3885 \pm 495$ \\
Pre-denudation & $32.2 \pm 7.4$ & $116 \pm 31$ & $603 \pm 340$ \\
\hline sst1 & $81.3 \pm 2.6$ & $350 \pm 63$ & $3406 \pm 481$ \\
L-797,591 & & $384 \pm 144$ & $3525 \pm 556$ \\
sst2 & $68.0 \pm 15.5$ & & $3558 \pm 430$ \\
L-779,976 & & $239 \pm 90$ & \\
sst3 & $68.1 \pm 16.0$ & & $2966 \pm 399$ \\
L-796,778 & & $\mathbf{1 8 6} \pm \mathbf{9 9 *}$ & $2454 \pm 405$ \\
sst4 & $\mathbf{4 9 . 6 \pm 1 4 . 9 \dagger}$ & & \\
L-803,087 & & $267 \pm 45$ & \\
sst5 & $\mathbf{5 4 . 8} \pm \mathbf{8 . 2 *}$ & & \\
L-817,818 & & & \\
\hline
\end{tabular}

$* p<0.05 ; \uparrow p<0.01$ 